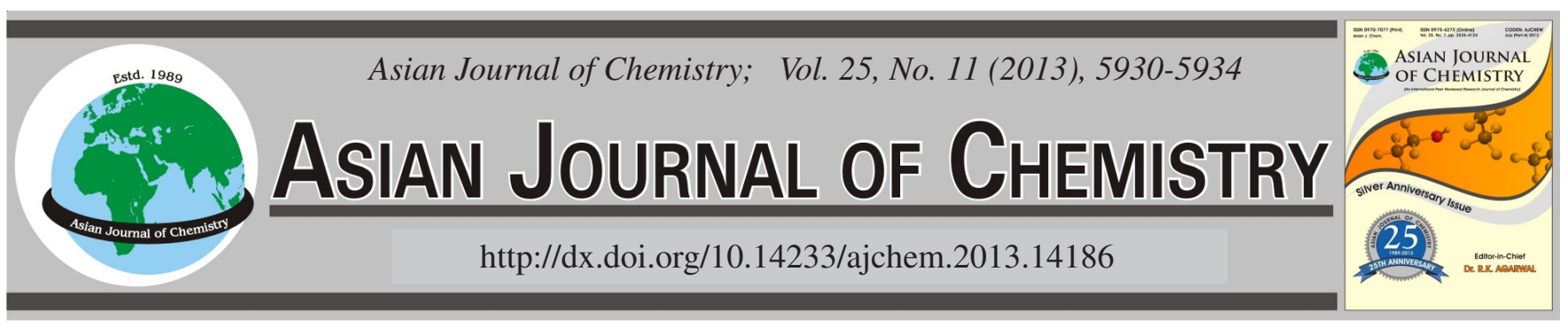

\title{
Thermal Stability and Drug-Excipient Compatibility Studies of Peppermint and Caraway Oils for Formulation of Chewable Tablets
}

\author{
Nikhil K. Sachan ${ }^{1, *}$, Seema Pushkar ${ }^{1}$, Anupam K. Sachan ${ }^{2}$ and S.K. Ghosh ${ }^{3}$
}

${ }^{1}$ University Institute of Pharmacy, Chhatrapati Shahu Ji Maharaj University, Kanpur-208 024, India

${ }^{2}$ Dayanand Dinanath College, Institute of Pharmacy, Kanpur-209 214, India

${ }^{3}$ Department of Pharmaceutical Sciences, Dibrugarh University, Dibrugarh-786 004, India

*Corresponding author: Fax: +91 512 2573231; E-mail: nikhilsachan@ gmail.com

(Received: 7 June 2012;

Accepted: 18 April 2013)

AJC-13370

\begin{abstract}
Drug delivery is highly innovative in terms of materials to assist delivery, excipients and technology which allows release of drugs in a manner desired for improved therapeutic efficacy, safety and patient compliance. Among many other factors cost of non-compliance alone estimated to be $c a .13 \%$ of total healthcare expenditure per year. Providing patients with simplified oral medications that will improve compliance and thus result more effective treatment has been one of the major drivers for innovation in the oral controlled drug delivery market. In this connection the oral chewable tablets were investigated as possible alternative formulations for the delivery | essential oils known to be effective for the treatment of various ailments and have been administered traditionally as aromatic waters, elixirs, or more recently in the soft gelatin capsules. Now-a-days when people are increasingly taking several products as breath freshener, the present concept to formulate these essential oils in the form of chewable dosage forms so that these can be administered for such therapeutic uses and can provide simultaneously breath freshness to consumer in view of the urban lifestyle. This paper discuss the thermal stability and drug-excipient compatibility studies of peppermint and caraway oils for formulation of chewable tablets as alternative dosage form towards improved patient compliance and market viability.
\end{abstract}

Key Words: Essential oils, Chewable tablets, Thermal studies, Drug delivery.

\section{INTRODUCTION}

Drug delivery is one of the frontier areas of research in the field of science and technology ${ }^{1}$. Drug delivery systems [DDS] play a vital role in performance of therapeutic moiety in vivo and its commercial viability; moreover the type of drug delivery system that will be chosen to meet a given clinical need will depend on a number of factors ${ }^{2}$. These include the route of administration, time required for onset of action, stability and physico-chemical properties of the drug, amount of drug delivered to the site of action through a dosage form, potency, safety profile and biological half life of the drug, need for localizing the effect of drug administered to a particular organ or tissue, cost of goods and ability of medicament to get absorbed from site of administration ${ }^{3}$. The essential oils have been used for the treatment of various ailments externally and internally, described in the pharmacopoeia, traditional systems of medicine and reported in folk medicine ${ }^{4}$. The peppermint and caraway oils too are having vide therapeutic utility for the treatment of non-ulcer dyspepsia, flatulence, gastritis also have antispasmodic, carminative, analgesic, flavouring properties ${ }^{5-8}$.
In India the two oils are used widely in different forms by common people for the relief of dyspepsia, gastric spasm and carminative purpose in the form of aromatic waters, soft gelatin capsules or as elixirs, moreover the people are taking several products as breath freshener. This approach of formulating these essential oils as chewable tablets enables the patient friendly administration of these oils for therapeutic purposes and provides simultaneously breath freshness to consumer in view of the urban lifestyle increasingly demanding the use of chewables as refreshing agents. This can be a tool for improved patient compliance which has been otherwise a critical problem in therapeutics. In a recent study New England Healthcare Institute reported ${ }^{9}$, the cost of non-compliance in US alone was estimated to be as much as $\$ 290$ billion or $13 \%$ of total annual healthcare expenditure. Providing patients with simplified oral medications that will improve compliance and thus result more effective treatment has been one of the major driver for innovation in the oral controlled drug delivery market ${ }^{10}$.

Chewable dosage forms have long been the part of pharmacist's armamentarium for administration of medicaments and delivery of essential oils through chewable tablets 
offers better palatability, by-passing first pass metabolism, better bioavailability through enhancing dissolution steps, patience convenience for the no need of water for swallowing, rapid onset of action, improved patient acceptance (especially in pediatrics) through pleasant and product distinctiveness from a marketing perspective, improved entrapment stability and comparative low production cost ${ }^{11}$. To formulate any medicament into new dosage form, a series of preformulation investigations are required. Assessment of stability and drug-excipient compatibly studies constitute an important part of such preformulation investigations which are explored in comprised study for peppermint and caraway oils.

\section{EXPERIMENTAL}

Peppermint oil (Arora Pharmaceuticals), caraway oil (Siva Aromatics), mannitol (Getec Ltd), dicalcium phosphate (Enar Chemie Ltd), hydroxy propyl cellulose (Dow Chemicals), Syloid (W.R. Grace), cabosil (Cabot Sanmar Ltd), stearic acid (Mallinckdrot), magnesium stearate (S. Kant Healthcare), Fl Novamint Peppermint 5060 40T (Firmenich), Fl Taste Mask Powder 501482 T P0424 (Firmenich), ProSolv SMCC50 (Penwest), nutra sweet powder (NutraSweet), Carbopol $974 \mathrm{P}$ NF (Noveon).

Planetary mixer (M/s Dito Sama, France), Tablet friability test apparatus (Arkey Labtromix, India), Monsanto tester (Aarkey Labtromix, India), Fluidized bed dryer (Retsch Gmbh \& Co, Germany), USP - Tapped density apparatus (Electrolab, India), Rotatory tablet compression-machine (Rimek, India), Mechanical stirrer (Remi, India), Digimatic caliper (Mitutoyo, Japan), Humidity chamber (Thermolab, India), 784KFP Titrino (Metrohm), HPTL Chromatography (Camag, Switzerland), I.R. moisture balance (Guru Nanak Instrument, India), Clarus500 Gas Chromatograph (Perkin Elmer).

Identification and quantification of marker: Identification of the marker compound was carried out by high performance thin layer chromatography (HPTLC) and the identified markers viz., menthol and carvone were quantified further using HPTLC and gas chromatograhy as described by Sachan et al. ${ }^{12}$.

Standard preparation: Accurately weighed $50 \mathrm{mg}$ of carvone was $50 \mathrm{mg}$ transferred into $10 \mathrm{~mL}$ volumetric flasks, respectively. Toluene was added in small portion to dissolve the sample and volume was made up. Menthol and carvone were further diluted to $300 \mathrm{mg} / \mathrm{mL}$.

Chromatography condition: The GC experiments were performed on a clarus-500 gas chromatograph. The sample was run in the column DB-1 $(30 \mathrm{~m} \times 250 \mu \mathrm{m})$ with reference of the standard carvone and menthol. The flow rate was 0.8 $\mathrm{mL} / \mathrm{min}$; temperature was maintained at $90^{\circ} \mathrm{C}$ for $5 \mathrm{~min}, 150{ }^{\circ} \mathrm{C}$ for $5 \mathrm{~min}$ and $230{ }^{\circ} \mathrm{C}$ for $10 \mathrm{~min}$, respectively. Injector and detectors were used at 250 and $280^{\circ} \mathrm{C}$, respectively. In HPTLC, the samples were applied in the form of bands on a precoated silica gel $\mathrm{GF}_{254}$ aluminium plate (Camag, LinomatIV, Switzerland). The solvent system of toluene and ethyl acetate (95:5) was used for the development, compound were detected by spraying anisaldehyde solution after drying at $105^{\circ} \mathrm{C}$ for $5 \mathrm{~min}$. The plate was visualized after spraying anisaldehyde sulfuric acid reagent. The scanning was done at $\lambda_{\max }-515 \mathrm{~nm}$ for carvone and $\lambda_{\max }-610 \mathrm{~nm}$ for menthol, using Camag TLC scanner 3.
Sample preparation: Ten tablets were taken and their average weight was calculated. The tablets were powdered and the quantity equivalent to $30 \mathrm{mg}$ of peppermint caraway oil was taken in a $50 \mathrm{~mL}$ volumetric flask and dissolved with a small portion of toluene by sonication for $10 \mathrm{~min}$. The solution was filtered through membrane filter (PALL Life Sciences \#0.45 m). The volume was made up with toluene.

Drug stability studies: The drug (peppermint oil and caraway oil) was packed in sealed glass vials individually and the admixture of both the drug at the ratio $1: 1$ were kept at different storage conditions, $5{ }^{\circ} \mathrm{C}, 25^{\circ} \mathrm{C}$ and $60 \%$ relative humidity and $40{ }^{\circ} \mathrm{C}$ and $75 \%$ relative humidity for 1 month and evaluated after interval of 1 week $^{13}$. After sample preparation as above, both the standard solution and sample were run in the column and analyzed. The peak areas were noted and the amount present in the formulation was calculated using the standard (Fig. 1).

Drug-excipients compatibility studies: Admixtures of the drug and excipients was mixed properly in proportions of $1: 5$, respectively and packed in glass vials, then compatibility studies 3 was done by storing at different storage conditions $5{ }^{\circ} \mathrm{C}, 25^{\circ} \mathrm{C}$ and $60 \%$ relative humidity and $40{ }^{\circ} \mathrm{C}$ and $75 \%$ relative humidity for one month and evaluated after interval of one week ${ }^{14-16}$.

\section{RESULTS AND DISCUSSION}

The quality of drug product should be maintained under the various conditions that pharmaceuticals encounter, during production, storage in warehouses, transportation and storage in hospital and community pharmacies, as well as in the home. Therefore, in view of the chemical degradation and physical degradation of drug substances may change their pharmacological effects, resulting in altered efficacy therapeutic as well as toxicological consequences; the pharmaceuticals should be stable and maintain their quality until the time of usage or until their expiration date ${ }^{17}$. In the present stability investigations carried out as per ICH guidelines, it revealed that there was no physically observable change found in peppermint and caraway oils (Table-1) and no significant loss of content of active drug occurred at storage condition/sampling intervals of $25^{\circ} \mathrm{C}$ and at $60 \%$ relative humidity for a period of 2 months. However, significant changes in both these parameters occurred at storage conditions/sampling intervals at $40^{\circ} \mathrm{C}$ and at $75 \%$ relative humidity for a period of 1 month (loss: 0.065 and $0.101 \%$, respectively) and two months (loss: 0.115 and $0.211 \%$, respectively) (Table-2). Moreover there was no any new peak or alteration of retention time observed for these samples when compared with zero time observations under similar conditions. Thus the two oils are sufficiently stable suitable for the formulation of chewable tablets (Fig. 2).

Further the safety and efficacy of medicines depends not only on the active principles and manufacturing process but this also depend upon performance of excipients ${ }^{18}$. The magnitude of this effect will depend on the characteristics of the drug and on the quantity and properties of the excipients. Chemical and physical stability of active ingredients in fixed combinations (FDC) dosage forms may become very complicated due to the presence of two or more active ingredients, or 

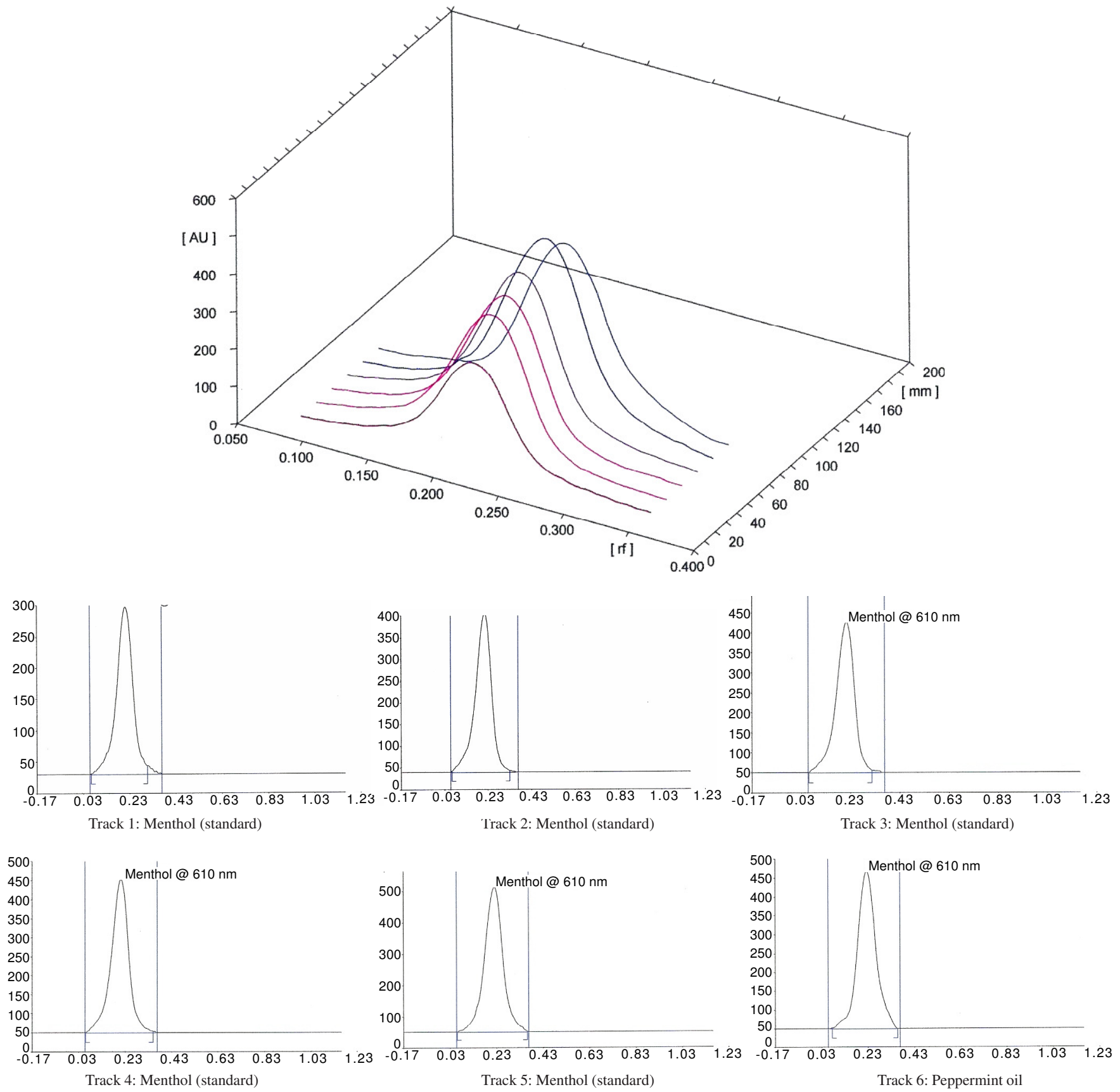

Fig. 1. (a) HPTLC chromatograms all tracks of standards (menthol) and sample at $610 \mathrm{~nm}$

TABLE-1

STABILITY STUDY OF PEPPERMINT AND CARAWAY OILS

\begin{tabular}{|c|c|c|c|c|c|c|c|c|c|c|c|c|}
\hline \multirow{3}{*}{ Storage conditions } & \multicolumn{12}{|c|}{ Material (Time) } \\
\hline & \multicolumn{4}{|c|}{ Peppermint Oil } & \multicolumn{4}{|c|}{ Caraway Oil } & \multicolumn{4}{|c|}{ Peppermint and Caraway oil (1:1) } \\
\hline & $\begin{array}{c}\text { Week } \\
1\end{array}$ & $\begin{array}{c}\text { Week } \\
2\end{array}$ & $\begin{array}{c}\text { Week } \\
3\end{array}$ & $\begin{array}{c}\text { Week } \\
4\end{array}$ & $\begin{array}{c}\text { Week } \\
1\end{array}$ & $\begin{array}{c}\text { Week } \\
2\end{array}$ & $\begin{array}{c}\text { Week } \\
3\end{array}$ & $\begin{array}{c}\text { Week } \\
4\end{array}$ & $\begin{array}{c}\text { Week } \\
1\end{array}$ & $\begin{array}{c}\text { Week } \\
2\end{array}$ & $\begin{array}{c}\text { Week } \\
3\end{array}$ & $\begin{array}{c}\text { Week } \\
4\end{array}$ \\
\hline $05^{\circ} \mathrm{C}$ & \multicolumn{12}{|c|}{ No any physical changes was found in the samples packed in glass vials } \\
\hline $25^{\circ} \mathrm{C}$ and $60 \% \mathrm{RH}$ & \multicolumn{12}{|c|}{ No any physical changes was found in the samples packed in glass vials } \\
\hline $40^{\circ} \mathrm{C}$ and $75 \% \mathrm{RH}$ & \multicolumn{12}{|c|}{ No any physical changes was found in the samples packed in glass vials } \\
\hline
\end{tabular}

TABLE-2

MARKER CONCENTRATION IN ACCELERATED STABILITY DATA

\begin{tabular}{cccccccc}
\multicolumn{10}{c}{ MARKER CONCENTRATION IN ACCELERATED STABILITY DATA } \\
\hline Specification & Initial & $\begin{array}{c}40{ }^{\circ} \mathrm{C} \text { and } 75 \% \\
\mathrm{RH} / 1 \mathrm{M}\end{array}$ & $\begin{array}{c}\text { Loss } \\
(\%)\end{array}$ & $\begin{array}{c}40{ }^{\circ} \mathrm{C} \text { and } 75 \% \\
\mathrm{RH} / 2 \mathrm{M}\end{array}$ & $\begin{array}{c}\text { Loss } \\
(\%)\end{array}$ & $\begin{array}{c}25{ }^{\circ} \mathrm{C} \text { and } 60 \% \\
\mathrm{RH} / 2 \mathrm{M}\end{array}$ & $\begin{array}{c}\text { Loss } \\
(\%)\end{array}$ \\
\hline Menthol & $0.775 \%$ & $0.71 \%$ & 0.065 & $0.66 \%$ & 0.115 & $0.75 \%$ \\
Carvone & $0.771 \%$ & $0.67 \%$ & 0.101 & $0.56 \%$ & 0.211 & $0.72 \%$ \\
\hline
\end{tabular}



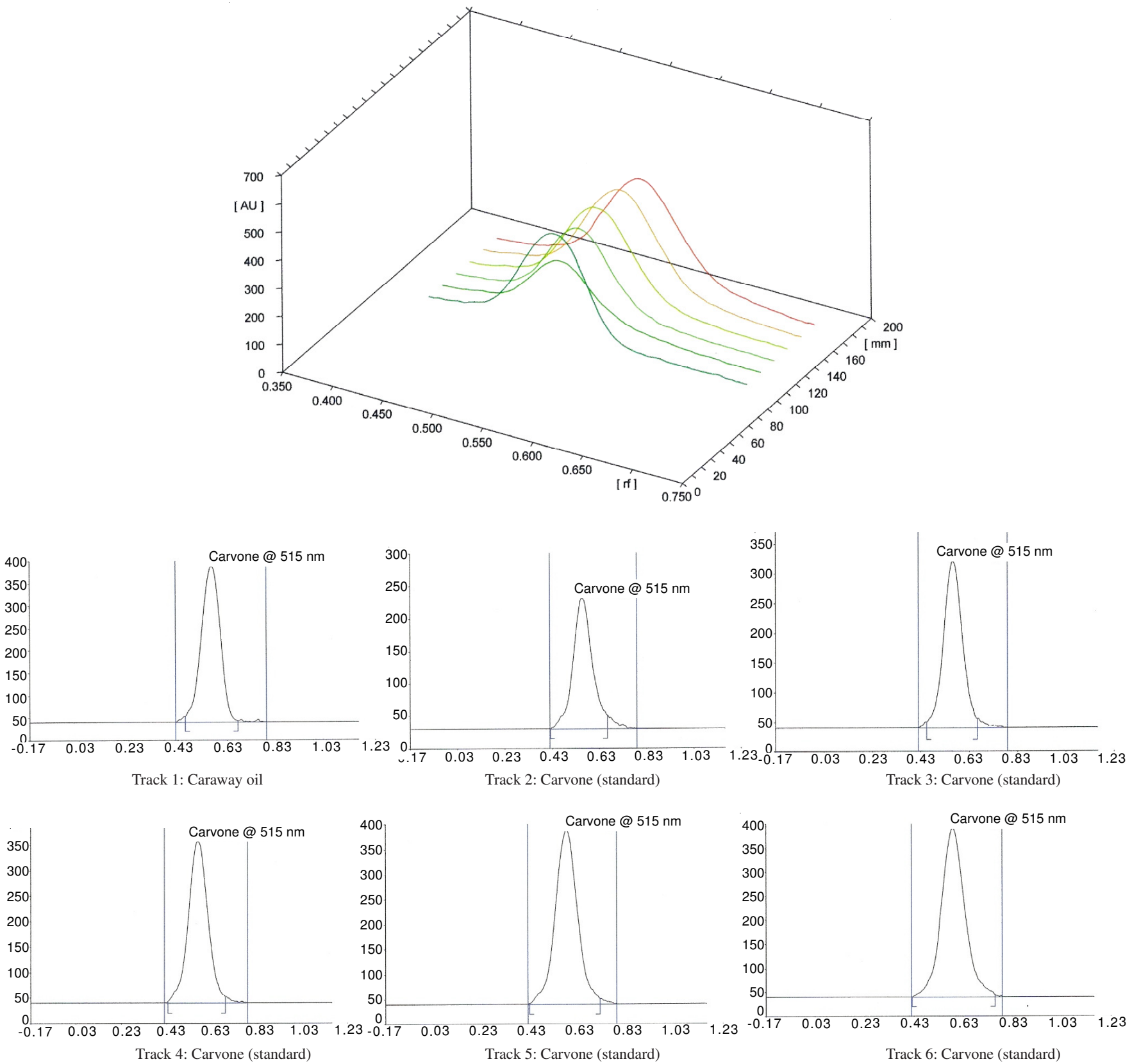

Fig. 1. (b) HPTLC chromatograms all tracks of standards (carvone) and sample at $515 \mathrm{~nm}$

because potentially more or unique excipients are required to achieve the desired release rate for both actives ${ }^{19}$. Not only active ingredients may react each other to form degradants which may not seen in single dosage form, but also active ingredients may react with excipients which are otherwise compatible with one of single active ingredients ${ }^{20}$. These attributes create many new challenges for formulation development and pharmaceutical analysis of fixed combination products. Strategic design in drug-drug and drug-excipient compatibility studies and development of appropriate analytical method which is able to detect all potential impurities and degradants, are very important in successfully developing a stable fixed combination dosage form ${ }^{21}$. The drugexcipient compatibility studies showed that there is no change at accelerated storage condition for a month time period (Table-3).

\begin{tabular}{|c|c|c|c|}
\hline \multicolumn{4}{|c|}{$\begin{array}{c}\text { TABLE-3 } \\
\text { DRUG-EXCIPIENT COMPATIBILITY STUDIES }\end{array}$} \\
\hline Storage time: Four weeks & & Packing: Glass vials & \\
\hline \multirow{2}{*}{ Composition of granules } & \multicolumn{3}{|c|}{ Stress conditions } \\
\hline & $5^{\circ} \mathrm{C}$ & $25^{\circ} \mathrm{C}$ with $60 \% \mathrm{RH}$ & $40^{\circ} \mathrm{C}$ with $75 \% \mathrm{RH}$ \\
\hline $\begin{array}{l}\text { Lactose, Sucrose, Mannitol, CMC Sodium, Mg stearate, Light Mg } \\
\text { carbonate, Di calcium Phosphate, Talc, Aerosil, Syloid, Starch, } \\
\text { Microcrystalline Cellulose, Ethyl Cellulose, Hydroxypropyl- methyl } \\
\text { cellulose, Stearic acid, Aspartame, ProSolv SMCC, Carbopol974P NF }\end{array}$ & $\begin{array}{l}\text { No physical changes } \\
\text { in samples and no } \\
\text { new peak observed } \\
\text { in GC. }\end{array}$ & $\begin{array}{l}\text { No physical changes in } \\
\text { samples and no new } \\
\text { peak observed in GC. }\end{array}$ & $\begin{array}{l}\text { No physical changes } \\
\text { in samples and no } \\
\text { new peak observed } \\
\text { in GC. }\end{array}$ \\
\hline
\end{tabular}




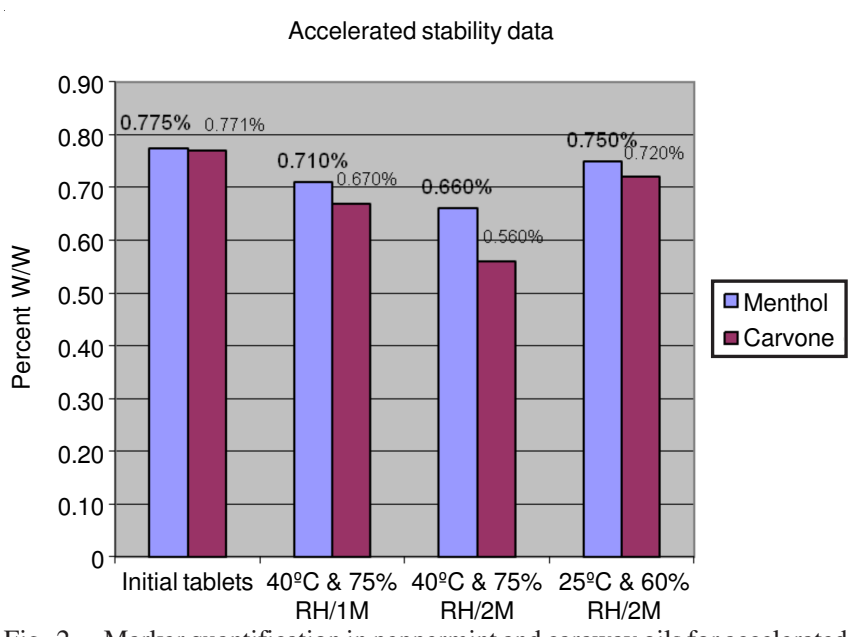

Fig. 2. Marker quantification in peppermint and caraway oils for accelerated stability testing

\section{Conclusion}

The present investigation revealed that the peppermint and caraway oils found sufficiently stable and without any marked chemical interaction with the tableting excipients for proposed chewable tablet formulation in view of their better patient acceptance/compliance through pleasant taste and product distinctiveness as well as through better palatability, fast onset of action over existing formulations additionally these formulations more commercially viable being capable faster and economic processing.

\section{REFERENCES}

1. N.K. Sachan and A. Bhattacharya, J. Assam Sci. Soc., 47, 34 (2006).

2. A.K. Sachan, N.K. Sachan, S. Kumar, A. Sachan and S.S. Gangwar, Eur. J. Sci. Res., 46, 194 (2010).

3. W.N. Charman, H.K. Chan, B.C. Finnin and S.A. Charman, Drug Dev. Res., 46, 316 (1999).

4. J.T. Coon and E. Erenst, Alimen. Pharmacol. Therap., 16, 1689 (2002).

5. British Herbal Medicine Association. British Herbal Pharmacopoeia, Part II. West Yorks, England: BHMA Publishers, pp. 23-25 (1979).
6. R.C. Wren, Potter's New Cyclopaedia of Botanical Drugs and Preparation, Essex, England: CW Daniel Co., pp. 59-60 (1985).

7. M. Wichtl, Herbal Drugs and Phytopharmaceuticals, Boca Raton, FL: CRC Press, pp. 128-129 (1994).

8. B. May, H.D. Kuntz, M. Kieser and S. Kohler, Arzneimittel-Forsch, 46, 1149 (1996).

9. New England Healthcare Institute [NEHI, Report, New Research on Patient Medication Adherence, Report: Cambridge MA. September 23, (2010) Available through: http://www.nehi.net/ (Accessed on May 29, 2011).

10. G.S. Rekhi, Advances in Solid Dose Oral drug Delivery. In: Oral Drug Delivery and Advanced Excipients, Frederick Furness Publishing, East Sussex, UK, pp. 14-18 (2010). Available through: www.ondrugdelivery.com/ (Accessed on May 29, 2011).

11. A.K. Sachan, Alternative Dosage Forms for Delivery of Essential OilsChewable Tablets, M.Pharm, Thesis, India: Bundelkhand University (2005).

12. N.K. Sachan, S.K. Ghosh and S. Pushkar, In eds.: A. Shrivastava and V. Nigam, Science of Polymeric Plant Based Excipients in Pharmaceutical Drug Delivery Systems, Proceedings of National Seminar on Global Perspectives of Biological Research in the Present Scenario, India: D.G.P.G. College, Kanpur, pp. 135-150 (2010).

13. ICH Harmonized Tripartite Guidelines: International Conference on Harmonization (ICH)-Guidance for Industry: Q1A(R2) Stability Testing of New Drug Substances and Products (2003) Available at: http:// www.fda.gov/downloads/RegulatoryInformation/Guidances/ ucm128204.pdf (Assessed, September 19, 2010).

14. L. Bhattacharya, S. Schuber, S. Sheehan and R. William, In eds.: A. Katdare and M.V. Chaubal, Excipients: Background/Introduction, Excipients Development for Pharmaceutical, Biotechnology and Drug Delivery System, New York: Informa Health Care, pp. 1-2 (2006).

15. IPEC: Qualification of Excipients for Use in Pharmaceuticals, International Pharmaceutical Excipients Council, Europe (2008), Available at: www.ipec-europe.org (Accessed on 27th August 2010)

16. H. Liberman, L. Lachman and J.B. Schwartz, Pharmaceutical Dosage Forms: Tablets, New York: Marcel Dekker Publisher, Vol. 1, edn. 2 (2005).

17. S. Yoshioka and V.J. Stella, Stability of Drugs and Dosage Forms, New York: Kluwer Academic Publishers, Vol. V-VI, pp. 1-2 (2002).

18. N.K. Sachan and D. Singh, J. Assam Sci. Soc., 46, 20 (2005).

19. B. Roger, T. Richard, H. Kimberly and A. Attaran, Malaria J., 8, 1 (2009).

20. P. Jin, S. Madieh and L.L. Augsburger, AAPS Pharm. Sci. Technol., 8, 105 (2007).

21. S. Klick, P.G. Muijselaar, J. Waterval, T. Eichinger, C. Korn, T.K. Gerding, A.J. Debets, C. Sänger-van de Griend, C. van den Beld, G.W. Somsen and G.J. De Jong, Pharm. Technol., 2, 48 (2005). 